\title{
Investigation of the Avdeevo Paleolithic Site: Intermediate Results and Perspectives
}

\author{
Medvedev $\mathrm{SP}^{1 *}$, Kandinov $\mathrm{MN}^{1}$, Lavrov $\mathrm{AV}^{2}$ and Tarasenko $\mathrm{KK}^{2}$ \\ ${ }^{1}$ Anuchin Institute and Museum of Anthropology, Lomonosov Moscow State University, Russia \\ ${ }^{2}$ Borissiak Paleontological Institute RAS, Russian Academy of Sciences, Russia
}

Submission: February 28, 2019; Published: March 15, 2019

*Corresponding author: Anuchin Institute and Museum of Anthropology, Lomonosov Moscow State University, Mokhovaya str. 11, Moscow 125009, Russian Federation, Russia

\begin{abstract}
Avdeevo is one the most remarkable Upper Paleolithic sites in the Central Russian Plane. Over the years of archaeological research there have been discovered 3 settlement units and been collected enormous assemblages of lithic and bone artifacts, pieces of portable art. But the problem of this units' synchroneity haven't been solved yet. Investigation of an unexplored area between these 3 units will give us an opportunity to reconstruct the Avdeevo site spatial organization.
\end{abstract}

Keywords: Upper Paleolithic; Avdeevo; Kostenki-Avdeevo culture; zooarchaeological data

\section{Mini Review}

The Avdeevo Paleolithic site is located in the western part of the Central Russian Upland, in the Kursk region of Russia, about $25 \mathrm{~km}$ west of the city of Kursk, on the right bank of the river Seym, at the confluence of the right tributary Rogozna river (Figure 1). Cultural remains were located on the first fluvial terrace at a depth of $1-1.5 \mathrm{~m}$ in sand and sandy loam layers, overlaid by cover loams and underlaid by alluvial sand deposits. Avdeevo was excavated by Voevodskij MV, Rogachev AN, Gvozdover MD, Grigor'ev GP, Bulochnikova EV and Medvedev SP. Three settlement units have been investigated during this time (Figure 2).

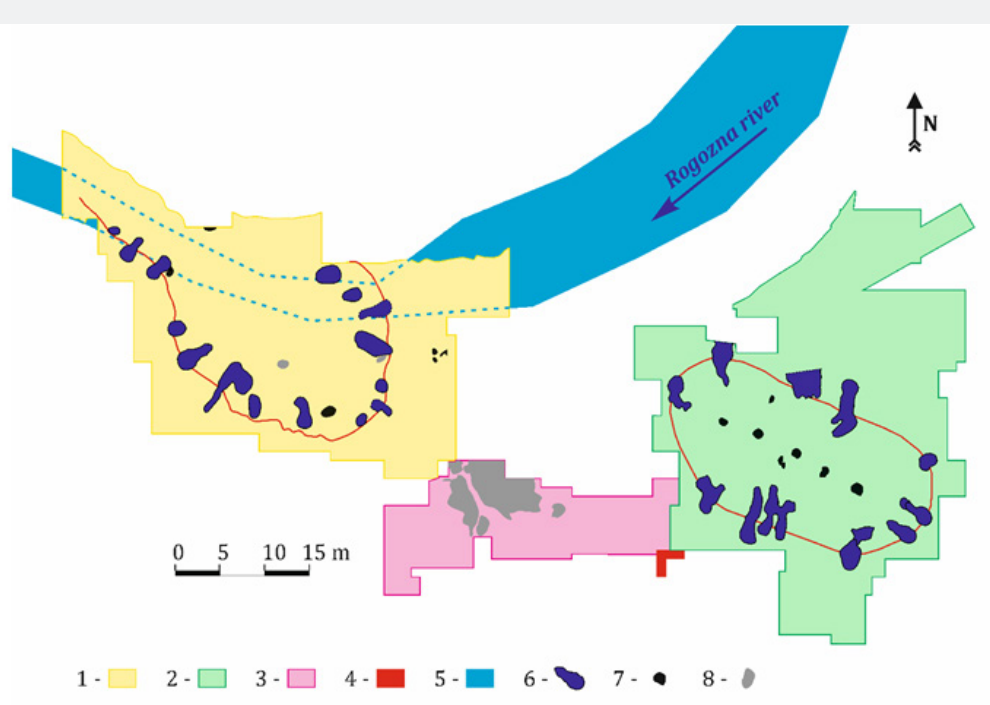

Figure 1: Eastern Europe map with sites mentioned in this review. 
Settlement units A and B were similar in many ways: lithic and bone inventories, art objects and spatial organization. Both units were represented by oval lenses of cultural layer, oriented with a long axis in the direction of NW-SE. Unit A had a length of $40 \mathrm{~m}$, a width of $20 \mathrm{~m}$, the northern third part was destroyed by a river Rogozna (contemporary river bed moved more southward and covered the territory had been explored already). Settlement unit B was smaller (30x15m) and located $30 \mathrm{~m}$ to the east. Several hearts were located in the center of ovals along the long axis ( 5 hearts for unit B; only 2 well preserved hearts for unit A). Cultural layer contained great number of animal bones, stone artifacts and charcoal, it was colored red with ocher (unit A) and black - with small charcoal fragments (unit B). Lenses of cultural remains were bounded at the edges by large pits (ranging from 1 to $16 \mathrm{~m} 2$ and to $1 \mathrm{~m}$ depth). Some of these pits were interpreted as semi-subterranean dwellings. Assemblages at Avdeevo are exceedingly rich: a great number of lithic and bone tools, numerous pieces of portable art (for example more than 20 female figurines made from ivory and marl) [1,2].

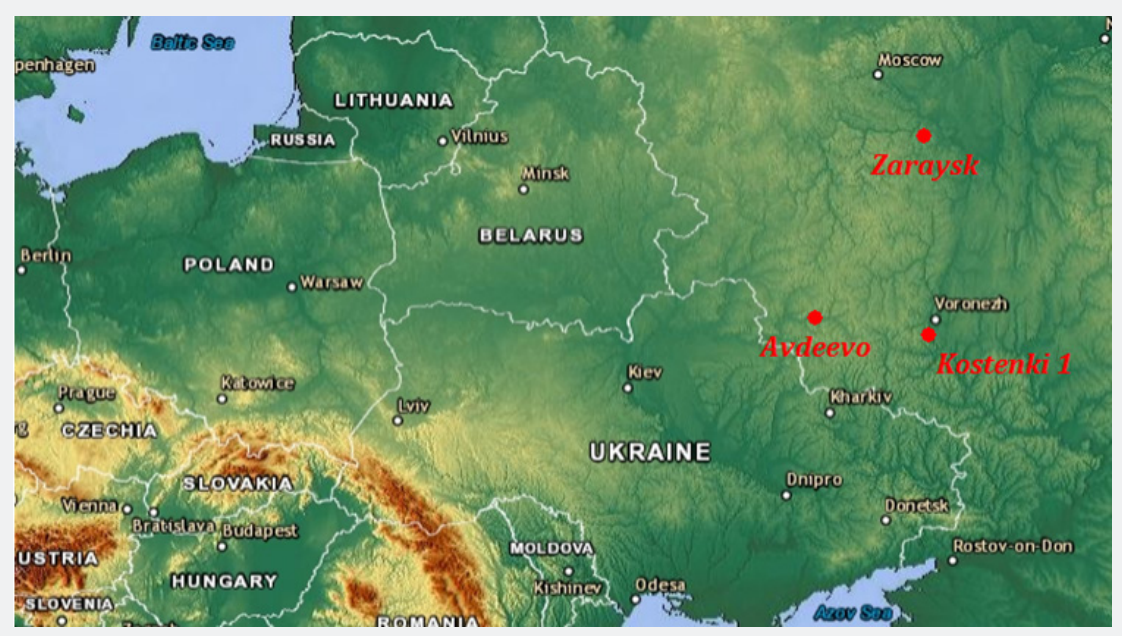

Figure 2: Avdeevo excavations plan: 1 - settlement unit A; 2 - settlement unit B; 3 - settlement unit C; 4 - trench 2018/7; 5 - contemporary bed of river Rogozna; 6 - large pit; 7 - hearth; 8 - ash lens.

Settlement unit $\mathrm{C}$ was located between 2 previous units - SE from unit $\mathrm{A}$ and $\mathrm{W}$ from unit B (Figure 2). Spatial organization of this unit was quite different - no large pits or hearts. Large ach lenses and high-density areas were discovered. This unit had some differences stratigraphic position of cultural remains, lithic inventory composition and typology [3]. Avdeevo has over 30 radiocarbon dates, most of them correspond into the interval 22000 and 21000 BP. There are some related sites in the Central Russian Upland such as Kostenki 1 - 1 cultural layer (on Don river, near Voronezh) and Zaraysk (in the Oka river basin, near Moscow). They are similar in specific tool categories in lithic assemblages (Kostenki knives, shouldered points, leaf-shaped points); bone implements; pieces of art and spatial organization of settlement units (for example, one of large pits in Avdeevo - unit B and one from Kostenki 1 - unit 2 had inside identical constructions - mammoth ossa longum put in a stack) [2]. This site form Kostenki-Avdeevo archaeological culture of Mid Upper Paleolithic.

In 2016 a new phase of investigation started by geophysical research of the territory between settlement units A and B, and on a wide space south of the site. Ground penetrating radar and geomagnetic analysis were carried out in order to characterize geological and geomorphologic structure of the first fluvial terrace. In 2017 five tranches (size $2 \times 1 \mathrm{~m}$ ) were excavated southward from the settlement unit $\mathrm{C}$ to explore distribution limit of Paleolithic remains. One of tranches contained 2 fragments of bone implements and 1 stone tool besides small bone and mammoth teeth fragments [4]. During the excavation of the 2018 field season it was investigated the territory at the border between settlements units B and C by a trench 2018/7. There were collected 10 flint artifacts and 250 pieces of faunal remains. Among bone items there were found some entire mammalian bones and identifiable fragments from which the following should be especially mentioned:

1. Canis lupus - 9th tail vertebra with a hole - vertebra caudal (Figure 3, 1a-1c);

2. Mammuthus primigenius - knee cap - os patella;

3. Bison priscus - corpus fragment of the thoracic vertebra;

4. Alopex lagopus - distal part of the os radius;

5. Alopex lagopus - proximal part of the os ulna with olecranon (Figure 3, 3);

6. Alopex lagopus - accessory carpal bone - os pisiforme;

7. Canis lupus - fragment of the lower jaw with one premolar (p3 and alveoli p2, m1 and roots fragment of p4) (Figure 3, 5); 

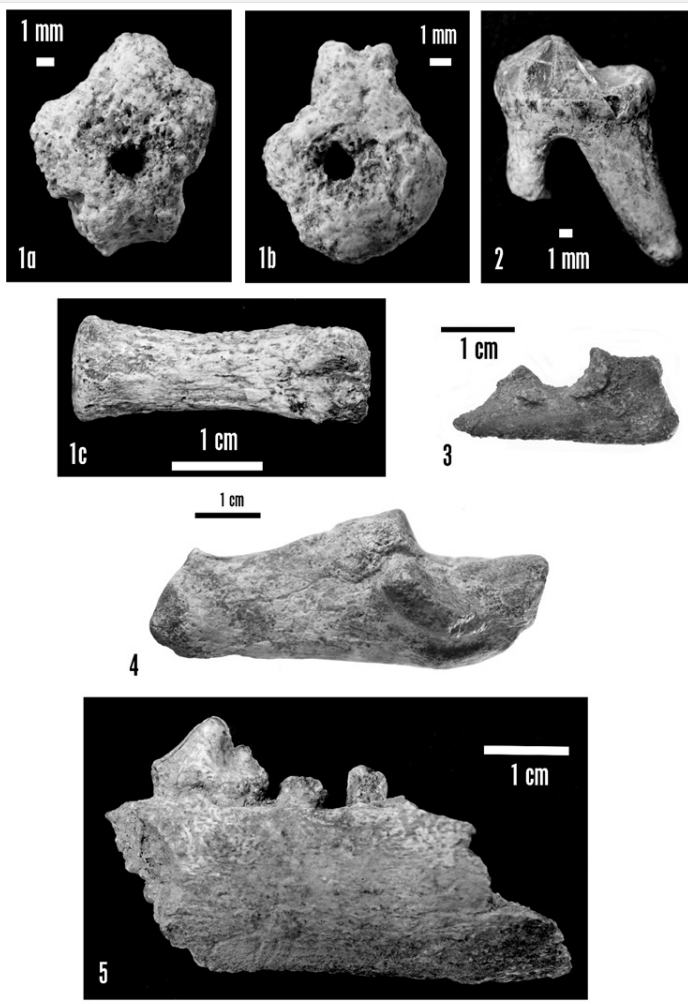

Figure 3: Findings of some bones of the field season 2018 at the Avdeevo site:

1. $9^{\text {th }}$ caudal vertebra with longitudinal canal (a - caudal view; b - cranial view; c - dorsal view).

2. Canis lupus left second lower molar $(\mathrm{m} 2)$, labial view.

3. Alopex lagopus proximal fragment of the right ulnar bone (os ulna), medial view.

4. Canis lupus left heel bone (os calcaneus), medial view.

5. Canis lupus fragment of the right mandibular horizontal ramus with $\mathrm{p} 3$ and $\mathrm{p} 4$ roots, lingual view.

8. Canis lupus - calcanear bone (os calcaneus) (Figure 3, 4);

9. Canis lupus - 2 upper incisors;

10. Canis lupus - $1^{\text {st }}$ upper premolar (P1);

11. Canis lupus $-5^{\text {th }}$ metacarpal bone (left forepaw);

12. Canis lupus - left $2^{\text {nd }}$ lower molar $\left(\mathrm{m}^{2}\right)$ (Figure 3,2$)$.

It should be noted that almost all bone finds belong to a predatory mammal: wolfs (Canis lupus) and arctic foxes (Alopex lagopus). All the bones of wolves found correspond to mediumsized wolves now living on the Russian Plain - for example, the length of $\mathrm{p} 3$ (third lower premolar) found was $13.2 \mathrm{~mm}$, the length of $\mathrm{m} 2$ (second lower molar) was $11.6 \mathrm{~mm}$. For the Avdeevo site, findings of bones in anatomical sequence and whole skeletons of arctic foxes and wolves are typical. Findings of bison bones are very rare (Table 1). Main interest is the Canis lupus tail vertebra with small holes (diameter $1.7 \mathrm{~mm}$ ) in both caudal and cranial tips (Figure 3, 1a-1c). We can with a high degree of confidence assume that the hole is through and of artificial origin. We are waiting for X-ray micro-CT and microware analysis results to confirm our hypothesis.
Table 1: Avdeevo, settlement unit B. List of identified faunal remains: MNB - Minimum Number of Bones; MNI: Minimum Number of Individual [4].

\begin{tabular}{|c|c|c|c|}
\hline Species & MNB & MNI & $\begin{array}{c}\text { Bones used } \\
\text { for MNI }\end{array}$ \\
\hline Mammutus primigenius & many & many & different \\
\hline Bison priscus & 6 & 1 & different \\
\hline Equus caballus cf. latipes & 58 & 3 & different \\
\hline Rangifer tarandus & 20 & 3 & different \\
\hline Saiga sp. & 2 & 1 & $?$ \\
\hline Coelodonta antiquitatis & 23 & 3 & Teeth \\
\hline Marmota sp. & $>500$ & 26 & Humerus \\
\hline Lepus sp. & 13 & 1 & Metapodium \\
\hline Citellus sp. & 1 & 1 & $?$ \\
\hline Spalax microphtalmus & 1 & 1 & $?$ \\
\hline Ursus arctos & 12 & 2 & different \\
\hline Canis lupus & 3000 & 63 & Calcaneus \\
\hline Alopex lagopus & $>6000$ & 130 & Calcaneus \\
\hline Gulo gulo & 263 & 15 & Mandibula \\
\hline Panthera spelea & 250 & 5 & Talus \\
\hline
\end{tabular}


There were 3 settlement units at the Avdeevo site. A problem of this units' correlation hasn't been solved yet. This is conversational question of settlement units' activity synchroneity or asynchroneity for exploring number of occupation phases during the site subsistence. New research will focus on an unexplored area between these units. Utilization of modern advanced techniques of archeological fieldwork, accompanied by detailed scientific research will help getting a direct stratigraphic section, which would connect 3 settlement units and help to find out the correlation between them. Archeological and scientific data will be aggregated in geoinformation system.

\section{References}

1. Gvozdover M (1995) Art of the mammoth Hunters. Oxbow Monograph Oxford, UK, 49: 186

2. Bulochnikova EV (1998) The sleeping pits and edge pits of the Upper Paleolithic sites Avdeevo and Kostenki. Herald of Anthropology 89: 9198.

3. Bulochnikova EV (2012) Avdeevo site: The Inter-Structures Space. In: Oshibkina S.V. Prehistoric Eurasia. IA RAS, Moscow, Russia, p. 37-58.

4. Gvozdover MD (2001) Zooarchaeology of the Upper paleolithic site Avdeevo. In: Rozanov A. Yu. Mammoth and Its Environment: 200 Years of Investigations. GEOS, Moscow, Russia, pp. 335-345.

\section{Your next submission with Juniper Publishers will reach you the below assets}

- Quality Editorial service

- Swift Peer Review

- Reprints availability

- E-prints Service

- Manuscript Podcast for convenient understanding

- Global attainment for your research

- Manuscript accessibility in different formats

( Pdf, E-pub, Full Text, Audio)

- Unceasing customer service

Track the below URL for one-step submission https://juniperpublishers.com/online-submission.php 